\title{
THE NARRATIVES OF ISLAMIC SCHOOL STUDENTS: \\ Contesting Salafism in a Saudi-Wahabi Educational Institutions in Contemporary Jakarta
}

\author{
Jajang Jahroni \\ Universitas Islam Negeri (UIN) Syarif Hidayatullah Jakarta \\ Email: jajang.jahroni@uinjkt.ac.id
}

\begin{abstract}
This article deals with the reproduction of knowledge within the Saudi-Wahhabi educational institution named LIPIA in Jakarta. Contrary to many studies which tend to see this institution as a monolithic entity, this article argues its knowledge reproduction is diverse as a result of different actors and the social contexts involved in the process. Besides students with modernist and traditionalist backgrounds are present in the institution, the Tablighis and the Salafis are also involved, shaping the reproduction of knowledge are more complex than expected. Each group of students are trying to influence the circumnstances they live in resulting in the diversity of knowledge. Furthermore, despite the Saudi state imposes certain subjects and disciplines to be followed by students, students have their own ways of shaping their knowledge. While in-campus program is well-organized, outcampus life is hardly ever to control as students develop their own network and socialization. Students are exposed to different types of Indonesian larger social contexts.
\end{abstract}

Keywords: Salafism, Wahhabism, Saudi Arabia, Indonesia, students, sheikh, knowledge, reproduction

DOI: https://doi.org/10.20414/ujis.v24i1.386

\section{Introduction}

THE RISE of modern Indonesian Salafism cannot be seen separated from the establishment of LIPIA (Lembaga Ilmu Pengetahuan Islam dan Bahasa Arab-Institute for Islamic Knowledge and Arabic), 
hereafter cited as the Ma'had. ${ }^{1}$ This is the first Saudi Arabia institute of higher learning in modern Indonesia that serves to transmit Salafism to Indonesia. ${ }^{2}$ Its origin goes back to the mid1970s, when Sheikh 'Abd al-'Azīz 'Abdullāh al-'Ammar, a prominent student of the Saudi Arabian Grand Mufti, Sheikh 'Abdullāh ibn 'Abd Al-Azīz ibn Bāz (1990-1999), paid a visit to Mohammad Natsir (1908-1993), an Indonesian modernist and a Muslim scholar who has a renowned international reputation. They talked about cooperation between both Indonesia and Saudi Arabia in education and $d a^{\prime} w a h$ activities. In the aftermath of this visit, the Ma'had was established in Jakarta. This institute was one of the most strategic Saudi institutions in Indonesia, one that helped to shape the transformation of Islamic knowledge in the country.

The al-Ammar-Natsir meeting symbolically marked the initial spread of Salafism in Indonesia. In 1978, the first group of Indonesian students was dispatched to Saudi universities, most notably the Islamic University of Medina. This campus has remained the most important destination for Indonesian students ever since. Another destination is the Islamic University of Imam Ibn Saud in Riyadh, called Jami'ah Imam, and Umm al-Qura Islamic University in Mecca. ${ }^{3}$

${ }^{1}$ The Ma'had is the nickname given by students. Its Arabic full name is Ma'had al-Ulum al-Islamiyya wa-l Arabiyya.

2 There are a number of scholarship on global Salafism and Salafism in Indonesia. See for instance Madawi Al-Rasheed, A History of Saudi Arabia (Cambridge: Cambridge University Press, 2002); Madawi Al-Rasheed, Kingdom without Borders, Saudi Arabia's Political, Religious and Media Frontier (London: Hurst \& Company, 2008); James L. Peacock, Muslim Puritans: Reformist Psychology in Southeast Asian Islam (Berkeley: University of California Press, 1978); Michaela Prokop, "Saudi Arabia: The Politics of Education," International Affairs 79, no. 1 (1994): 77-89; Fauzan Saleh, Modern Trends in Islamic Theological Discourse in Twentieth Century Indonesia, a Critical Survey (Leiden: E. J. Brill, 2001); Roel Meijer, ed., Global Salafism: Islam's New Religious Movement (London: C. Hurst \& Co. Publishing Ltd., 2009).

${ }^{3}$ On education and politics of education in Saudi Arabia, see Maher Abouhaseira, "Education, Political Development and Stability in Saudi Arabia" (Ph.D. Dissertation, University of Southern California, 1998); Yahya S. Al-Hefdhy, "The Role of the Ulama (Islamic Scholars) in Establishing an Islamic Identity for Women in Saudi Arabia" (Ph.D. Dissertation, The Florida State University, 1994). 
Various scholars have paid attention to the Ma'had's roles and have seen it either as a modernist project, ${ }^{4}$ a Wahhabi school, ${ }^{5}$ a radical agent, ${ }^{6}$ a Saudi-inspired Salafi institution, ${ }^{7}$ or a transmitter of Salafi doctrines. ${ }^{8}$ While these studies are useful, they do not discuss the reproduction of knowledge within the $\mathrm{Ma}^{\prime}$ had in a fair way as it involves a wide range of actors. As a result, they fail to observe the diversity of knowledge within the Ma'had. Ever since its inception in the early 1980s, the Ma'had has become the locus where actors from different social and historical backgrounds actively engage in understanding the meaning of Salafism.

\section{The Spheres of Knowledge Reproduction}

This article concerns knowledge reproduction. Knowledge reproduction refers to the situations where different actors participate in transmitting the knowledge. ${ }^{9}$ Histories, agencies, and social structures where the actors are exposed are taken into account which result on the diversity of knowledge. As a result, any monolithic ideas on the knowledge reproduction should be rejected as it does not fairly take into account the situations to which the knowledge is produced and transmitted. Histories are important which shape people produce and reproduce their knowledge. The term histories can be wide such as the grand

${ }^{4}$ Asna Husin, "Philosophical and Sociological Aspects of Da'wah: A Study of Dewan Dakwah Islamiyah Indonesia" (Ph.D. Dissertation, Columbia University, 1998).

${ }^{5}$ Martin van Bruinessen, "Genealogies of Islamic Radicalism in Post-Suharto Indonesia," South East Asia Research 10, no. 2 (2002): 117-154.

${ }^{6}$ Noorhaidi Hasan, "Saudi Expansion, The Salafi Campaign and Arabized Islam in Indonesia," in Kingdom without Borders, Saudi Arabia's Political, Religious and Media Frontier, by Madawi Al-Rasheed (London: Hurst \& Company, 2005), 263-282.

${ }^{7}$ Imdadun Rahmat, Arus Balik Islam Radikal (Jakarta: Erlangga, 2005).

${ }^{8}$ Din Wahid, "Nurturing The Salafi Manhaj: A Study of Salafi Pesantrens in Contemporary Indonesia" (Ph.D. Dissertation, Utrech University, 2014).

${ }^{9}$ On the knowledge reproduction see Robert W. Hefner, Hindu Javanese: Tengger Tradition and Islam (Princeton, NJ: Princeton University Press, 1989); Pierre Bourdieu, Outline of a Theory of Practice (New York: Cambridge University Press, 2007); Fredrik Barth, Balinese World (Chicago: The University Press of Chicago, 1993); Clifford Geertz, The Religion of Java (Chicago: University of Chicago Press, 1976). 
narratives of people, it can also the stories of families and friendship which eventually shape the paths of further generations. Meanwhile the social structures are the systems which may include the social configuration of society as well as power and power-relations. ${ }^{10}$

As I will demonstrate throughout this article, students have different strategies to face the system imposed by the Ma'had. While they show respect and obedience to the rules inside the classroom, outside the classroom, knowledge sharing and discussion among students are actively taking place. Furthermore, in the aftermath of their studies, while enjoying various network provided by the Saudi government, students have their own decision to further interpret the knowledge they previously learned.

The term actor does not only limit to students, it also includes professors or Sheikh who are teaching in the Ma'had. Students are of course important actors who become the main focus analysis of this research. ${ }^{11}$ They are the transmitters of Salafism to Indonesian Muslims. It is important to note that the Ma'had initially requires all students to stay in the dorm. However, since the dorm was not able to accommodate all students, it allowed them to rent houses or apartment around the dorm. This policy is to control students from being contaminated by other teachings or ideologies which do not fit with the Ma'had's goal.

The Ma'had was founded in 1980. When it was still located in Salemba, Central Jakarta, it was called LPBA (Institute for Science and Arabic), and with 150 students, the Ma'had began its mission in the same year. Classes were held in the afternoon, to give students and people who had other activities in the morning the

${ }^{10}$ On the social structures of knowledge reproduction, see Hefner, Hindu Javanese; Bourdieu, Outline of a Theory on power and power-relation, see Michel Foucault, Power/Knowledge: Selected Interviews and Other Writings, 1972-1977, ed. Colin Gordon, 1st American Ed edition. (New York: Vintage, 1980).

${ }^{11}$ On the agencies, see for instance Benjamin C. Fortna, Imperial Classroom: Islam, the State and Education in the Late Ottoman Empire (Oxford: Oxford University Press, 2000); Gregory Starret, Putting Islam to Work: Education, Politics and Religious Transformation in Egypt (Berkeley: University of California Press, 1998). 
opportunity to join its programs. In 1990, the Ma'had moved to South Jakarta. Located in the Buncit area it now occupies two sixfloor buildings and has now 2,500 students, 25\% of them girls. ${ }^{12}$ The Ma'had is a state institution and under the supervision of the Islamic University of Muhammad ibn Saud in Riyadh, popularly called Jami'ah Imam, while its daily operation is supervised by the Saudi Embassy in Jakarta.

The reproduction of knowledge in the Ma'had takes place in three main venues: class, mosque, and library. From Monday to Friday, from 7.30 AM to 3.30 PM, classes are held in the first building (from the third to sixth floors). Arabic is used as the language of instruction. The teachers or lecturers are called ustādh for males and ustädhah for females, meaning teacher or professor. Some senior ustādh, especially those of Arab of origin, are called sheikh. Most ustādh are graduates from Jami'ah Imam in Riyadh. Disagreement is rare and when it occurs, students do not necessarily express their opinion in the classroom but they may send a letter or go to their teachers' office and talk. ${ }^{13}$

Around 12 PM, when the call for noon prayers is heard, all classes are dismissed. Students attend the mosque, which is located on the fourth floor of the second building. The congregational prayer begins at $12.30 \mathrm{PM}$ when all the students are presumed present. It is worth noting that there should only be one congregational prayer attended by the entire school community. The logic behind this is to cement solidarity and in-group feeling of the community. Second or third congregational prayers are only permissible under specific conditions, e.g. when there is not enough space in the mosque. Female students pray on the second floor while a microphone and CCTV connects them with the mosque. After praying, a sheikh or an ustädh usually delivers a sermon. Repeatedly the speaker will remind the attendants that bid'ah is heresy and that engaging in bid'ah will lead people to Hell.

12 The number of students has now increased but not significantly. There are many reason for this. The most important reason is that improving quality of Islamic institutes in the country either public or private which provide more choices for students to study.

${ }^{13}$ This rule is certainly ensured by the Ma'had from time to time. Violation against this rule may result on student dismissal. 
It is an effective means to advocate Islamic teachings and to maintain the spirit of puritanism among the students.

\section{State Schooling Project}

Some anthropologists have discussed the role of the state in the reproduction of knowledge. This Ma'had can be called state schooling. ${ }^{14}$ State schooling is a disciplinary institution in which the state seeks to control the reproduction of knowledge of students. In the modern period, cooptation by the state is crucial as the state increasingly penetrates the schools and seeks to control the knowledge of its citizens. Starret calls this process functionalization, "a process of translation in which intellectual objects from one discourse come to serve the strategic or utilitarian end of another discourse" ${ }^{15}$ State schooling was also founded in the course of Islamic history. During the downfall of the Ottoman Empire in the nineteenth century, the sultan built schools across the country to block the infiltration of Western missionaries' influence. Their tasks were to redefine the Empire's historical trajectories, to redraw the borders between the Ottomans and the West, and to rearticulate the roles of the state in society. ${ }^{16}$

In the nineteenth and twentieth centuries, madrasa were built within the Muslim communities to challenge the rise of the Western educational system built by Western colonial administrations. This led to a dichotomy in the education system in many parts of the Muslim world. Elites usually attended Western schools, through which they were able to build careers as colonial administrators, whereas ordinary Muslims, maintaining their cultural legacies, attended the madrasa system. In India, madrasa were built not only to challenge the encroachment of British schools but also to preserve Muslim identities and cultures

${ }^{14}$ On state schooling, see Fortna, Imperial Classroom; Robert W. Hefner and Muhammad Qasim Zaman, eds., Schooling Islam: The Culture and Politics of Modern Education (Princeton, NJ: Princeton University Press, 2007); Starret, Putting Islam to Work.

${ }^{15}$ Starret, Putting Islam to Work, 9.

${ }^{16}$ Fortna, Imperial Classroom. 
under the domination of the Hindu majority. ${ }^{17}$ Madrasa are the last bastions where Muslims seek refuge to preserve their religious orthodoxy. Apart from the politics of education, some scholars assert that the rise of madrasa within the Muslim communities was related to the high demand for standardizing and normativizing Islamic knowledge. The rise of madrasa is thus part of the recentering and the homogenization of religious knowledge. This can be seen in the championing of figh as the queen of religious science. It is the process of canonization in which knowledge was standardized based on written authoritative sources. ${ }^{18}$

Despite of the roles of the state, the project of state schooling has largely failed to produce the desired singularity of knowledge. This is because actors had the opportunity to produce knowledge deemed in support of their interests. "While the school may be a mechanism of diffuse and invisible power, it is also an engine of tension and contradiction". ${ }^{19}$ Given the fact that actors are exposed to larger social settings and that they have different historical backgrounds, the reproduction of knowledge is marked by a huge diversity.

As a state institution affiliated with Saudi Arabia, all the professors who teach at the Ma'had are appointed with the endorsement of Riyadh. They are state officials responsible for promoting Islamic education in line with the interests of Saudi Arabia. One of the officials is Mohammed Salīm al-Makkī. After completing his degree at the Faculty of Islamic Theology at the Jami'ah Imam in Riyadh, he was appointed as young lecturer there. After working at several posts at home, he was sent to Jakarta in 2010. He represents the newly emerging Saudi 'ulama' after the seizure of the Grand Mosque of Mecca in 1979 led by the extremist Juhaymān al-'Utaybī. ${ }^{20}$ Al-Makkī admitted that while maintaining

17 Noor, Farish A, Yogindar Sikand, and Martin van Bruinessen, eds., Madrasa in Asia: Political Activism and Transnational Linkages (Amsterdam: Amsterdam University Press, 2008).

${ }^{18}$ Hefner and Zaman, Schooling Islam.

${ }^{19}$ Starret, Putting Islam to Work, 12.

${ }^{20}$ On the seizure of the 1979 Grand Mosque of Mecca and its aftermath, see Thomas Hegghammer and Stephane Lacroix, "Rejectionist Islamism in Saudi Arabia: The History of Juhayman al-Utaybi Revisited," International Journal for 
its status as a state institution, the Ma'had failed to control the reproduction of the knowledge of its students. This is because students are exposed to a multiplicity of socialization and opportunities.

\section{The Politics of Scholarship}

There are two qualities that differentiate the Ma'had from other Islamic institutes: (1) its specialization in Islamic law and Arabic, and (2) the availability of scholarships. ${ }^{21}$ It is generally known that having religious knowledge, at least for individual purposes, is considered a good thing. This is even more so if one is able to offer religious teachings to other Muslims. People with deep religious knowledge are highly respected within the Muslim community. Many Muslim parents expect one of their children to study Islamic knowledge more in depth so that they can teach the other family members who have not acquired it.

Students will master religious knowledge much better when they have proper Arabic language skills. These skills not only include the ability to read, but also to speak. The trend to know Arabic is the result of a campaign launched by Gontor Islamic boarding school and its affiliates, which popularized Arabic reading and speaking skills. ${ }^{22}$ Because of this campaign, more people started to study Arabic. The number of students of the department of Arabic in many Islamic institutions of higher learning steadily increased and competed with the number of students studying English. There was a great demand among the Muslim population to learn Arabic as it is considered one of the

Middle East Studies 39 (2007): 103-122; Natana J. Delong-Bas, Wahhabi Islam: From Revival and Reform to Global Jihad (New York: Oxford University Press, 2004).

${ }^{21}$ On the Saudi Arabia politics of scholarship, see Jajang Jahroni, "The Political Economy of Knowledge: Sharia and Saudi Scholarship in Indonesia," Journal of Indonesian Islam 7, no. 1 (June 2013): 165-186.

22 Pesantren Darussalam Gontor in Ponorogo, East Java, established in 1926, is one of the Islamic boarding schools in Indonesia that officially uses Arabic and English as languages of instruction. In the 1970s, across the country, its alumni established the same model of boarding schools. Gontor is one of the largest Islamic boarding schools in Indonesia that participates in promoting Arabic among the Muslim population. 
symbols of Islam..$^{23}$ Muslims were defined as modern not only by having the ability to speak English; they also should be able to speak Arabic. Bearing this in mind, the introduction of Arabic by the Ma'had was very timely. It attracted a large number of Muslim students to apply.

The availability of scholarships, called mukafa'ah (stipend) is another reason for students to come to the Ma'had. In theory, students used to receive their scholarship monthly. In practice they got it once every two to three months, depending upon the speed of fund transfers from Riyadh. At the end of the month, students lined up in front of the administration office awaiting their turn to sign and take their money. One by one, their names were called and a staff member gave them their money in sealed envelopes through a small window. This cash system remained in practice until bank transfers replaced it in 2012. Regardless of its unpredictability, mukafa'ah ensures that students are able to pay their rent and can buy food. ${ }^{24}$

Apart from mukafa'ah, students also receive textbooks, and for the entire duration of their studies, they are not required to pay tuition fees. The availability of these scholarships is remarkable given the fact that most Islamic educational institutions in Indonesia do not provide stipends. As it is known, all throughout Islamic history, Muslim students enjoyed the fruits of charity to support them and to enable them to concentrate on their studies. This is the reason of why Muslim scholars were able to write their works. In the post-nation state, this practice seriously decline as the state monopolizes public money. ${ }^{25}$ Saudi Arabia seeks to revive this practice throughout its education institutions. However, this

${ }^{23}$ There have been more concerns that Muslims should give more attention to the Islamic symbols in public life in the 1980-90s. See for instance Nancy J. Smith-Hefner, "The New Muslim Romance: Changing Patterns of Courtship and Marriage among Educated Javanese Youth," Journal of Southeast Asian Studies 36, no. 3 (2005): 441-459.

${ }^{24}$ During the medieval Islam, scholars had enjoyed various scholarship taken from charities which enable them concentrate on their works. See for instance George Makdisi, The Rise of College, Institutions of Learning in Islam and the West (Edinburgh: Edinburgh University Press, 1981).

${ }^{25}$ See Michael Gilsenan, Recognizing Islam, Religion and Society in the Modern Middle East (London and Canberra: Croom Helm, 2000). 
practice is inescapably linked with politics. It is obvious that, on the one hand, Saudi Arabia uses scholarships as a political tool through which it promotes its ideologies. On the other hand, students also respond to this action in different ways, making the reproduction of knowledge in the Ma'had far from being uniform.

\section{The Background of the Students}

As one can easily predict, most students are the graduates from top madrasa and Islamic boarding schools in the country. Most of them are from cadres of modernist Muslim organizations particularly DDII, followed by Persis, al-Irshad and the Muhammadiyah. The NU seems to have the smallest group of students to benefit from this scholarship provision. If there are NU students, they have to have come to the Ma'had on their own accord but probably not as representatives of the organization. ${ }^{26}$

One of the students whom I owe my debt during my research is Nafis. He is from Garut, West Java. Garut is the stronghold of Persis, a modernist organization concerned with religious purification. His father, aged 65, was a local teacher who had previously studied in a local Persis madrasa. Like many Persis followers, his father was concerned with the fact that some Muslim people still practiced local rituals such as visiting saints' graves to seek baraka (blessing) and that they continued to commemorate the dead. In his youth, he had even campaigned to boycott these rituals, which he considered bid'ah. Being a puritan, so to speak, his father only performed rituals that were clearly supported by hadith. He performed various supplementary prayers (șalāh sunnah) and he read the al-awrad al-ma'thürāt (the dhikr practiced by the Prophet Muhammad). His father's puritan attitude influenced the entire family including his mother whose extended family still made offerings to their ancestral spirits. Nafis

${ }^{26}$ This issue remains debatable. According to some sources, from the beginning, the number of traditionalist students remained high, around $75 \%$, even though they were not prioritized like modernist students. The number of modernist students significantly increased when, in 2001, the authorities fully recognized the certificates of the Ma'had. Personal interview with Ibrahim al-Fati, January 2015. 
said that his father gradually advised his mother to abandon those practices and he taught her how to walk the right path of Islam.

The religious orientation of the family also influenced that of Nafis. He imitated what his father did and he took him as his model for how to live as a Muslim. Apart from providing religious orientation, his father also taught him how to be pious and how not to abandon the Sharia. Being a seeker of knowledge, his father advised him to keep his stomach almost empty and not to eat too much as too much food affects the entire body and may lead to sleepiness and laziness. He was urged to fast every Monday and Thursday as fasting is good for people's mental and physical health. His father's religious training was also completed by qiyām al-layl (waking up during the night), to pray to God while other people were asleep. By doing so, the seeker of knowledge would be really keen and able to grasp the knowledge of God. During Ramadhan these practices were intensified and he was expected at least to finish his khatm (completing reading of the all the chapters of the Qur'an) once during this month. While fasting during the day, he went to the local mosque at night. It was in the mosque that his enthusiasm to study in the Ma'had emerged. During Ramadhan, Ma'had students return home for a break. The local mosques in their hometowns invited them to deliver sermons before the congregants and in many cases, these sermons were delivered in Arabic. Nafis was impressed with their fluency in Arabic and with their ability to quote verses or hadith in support of their arguments. His father was supportive when he said that he would like to continue his study in the Ma'had. To this end, as required by the Ma'had, Nafis had to memorize at least two chapters of the Qur'an.

Another student was named Sugiono, a senior student. He had to take care of the new students who lived in the dorm for a transitional period. He was from Gresik, East Java. His background was highly Javanese and he comes from a group of people usually termed as abangan who are syncretic Javanese who still perform rituals from Hindu-Buddhist and animist traditions. In former times, there have been extensive conflicts between abangan and santri, the pious Muslim group leading to social and political divisions between both groups. In the 1980s, because of 
increased social encounters, the division between abangan and santri, especially at public universities became blurred. Abangan eventually went through a kind of re-Islamization after they had become involved in Islamic movements. Many of them became committed Salafis and joined Salafi organizations. ${ }^{27}$ Having secular educational backgrounds, they have non-religious jobs and work as finance experts, managers, and technicians and they assist Salafi scholars who have a religious educational background.

Before attending the Ma'had, Sugiono had studied for six years at the Ma'had al-Furqon al-Islami, one of the largest Salafi madrasa in Indonesia. He had been introduced to Salafism long before he attended the Ma'had and he had studied the Sharia and Arabic. Compared to Nafis, Sugiono is very puritan. This is related to his historical background where he experienced a sort of "leap of faith." As he is a Salafi cadre member, he is expected to expand the Salafi community in his hometown. As a result, he is a hardworking person and very disciplined more than any other student. Up to now, he has memorized eight chapters of the Qur'an, which means that he has been able to reach the number of chapters required for graduation. This means that students should at least memorize one chapter each semester (eight semesters in total, or four years). It is relevant to note that memorizing the Qur'an is the most difficult task and the main reason many students fail or drop out. He said that he had already memorized the Qur'an many years ago when he was still in Gresik. He just imitated his teachers many of whom were hăfiz (person who has memorized the entire Qur'an-thirty chapters). He had not changed his discipline when he attended the Ma'had. In the morning, after morning prayer, he would sit on his rug for about an hour or so to repeat the chapters he had already memorized. During breaks, he would take out his pocket Qur'an, hum the text and start a new chapter, which he would repeat the next morning.

Besides the Qur'an, Sugiono also memorized a number of hadith related to religious practices. He was keenly aware of the arguments on the prohibition of the commemoration of the dead, visiting saints' graves to receive blessing and many other practices,

${ }^{27}$ Hasan, “Saudi Expansion.” 
which he considered bid'ah. He had done this many years ago when he was sent to remote areas to conduct $d a^{\prime} w a h$ salafiyah (Salafi propagation). Like any young preacher, he had to go through this process. In the field, he was forced to face the local Muslim population who kept practicing their alien rituals. His teachers advised him to memorize various hadith to counter their arguments. It was clear that he was keen to engage in Salafi $d a^{\prime} w a h$ to whichever person he met. He loved to talk for hours to explain Salafi teachings. Having my mobile phone number, he kept texting me Islamic messages during Ramadhan. He reminded me of the month's virtues especially during the last uneven nights when laylah al-qadr (the night when the Qur'an was revealed, having virtues better than a thousand months) was most likely to occur. His texted me again on Idul Fitri and he expressed the wish that Allah might accept our devotions and that we may return to our fitrah (God's way of creating).

Unlike many other students who were active outside campus, Sugiono focused on his studies. He would sit in the library during the day and stay in his room during the night. Sometimes he came to the dorm office to make sure that everything was all right. The niyyah (intention) for seeking knowledge should be restored at all times, which accords with the Ma'had's goal of being an institution for tafaqquh fi al-din (understanding on religious matters). Seeking knowledge is highly respected in Islam and learned men have the obligation to teach other Muslims who do not possess religious knowledge. He disagreed with students who spent most of their time in a so-called harakah ${ }^{28}$ (movement) or a kajian $^{29}$ (study club) as it would lead them to the wrong direction. Although the Ma'had officially did not forbid student

${ }^{28}$ Harakah refers to Ikhwan-inspired students who regularly organize meetings outside campus to discuss the thoughts of Ikhwan scholars. They are called Tarbiyah, a group, which inspired the Welfare and Justice Party (PKS), an Ikhwan-inspired political party. In relation to this, see for instance Ali Said Damanik, Fenomena Partai Keadilan, Transformasi 20 Tahun Gerakan Tarbiyah di Indonesia (Jakarta: Teraju, 2002).

${ }^{29}$ In this context, the term kajian refers to Nahdhatul Ulama students who regularly discuss the ideas of contemporary 'liberal' Muslim thinkers like Hassan Hanafi and Nasr Hamid Abu Zaid. 
organizations, it would dismiss students who participated in demonstrations or who protested against the Indonesian government or the Ma'had.

\section{Why They Became "Salafis"}

Salafis perform rituals and practices are believed to have been exemplified by the Prophet Muhammad. According to Sugiono, to become a Salafi means that one should set out on a long journey. Many years ago, when he was introduced to Salafism for the first time, his teacher taught him to look for answers in the Qur'an and in the Sunnah every time he faced problems: What does the Qur'an have to say about this issue? What does the Sunnah say about it? Is it allowed? Is it recommended? If the Qur'an and the hadith do not address the problem, look at the opinion of the pious Salafi ulama, they have inherited the Prophet's authority to talk about Islam. The Qur'an says, "So ask the people of the message if you don't know" (QS 16:43). He argued that Salafism is a method by which Muslim believers practice Islam by returning to the Qur' an and the Sunnah. As Islam is considered the perfect way of life, it does not need any addition, nor may anything be omitted. Therefore, if the Qur'an says something, there is no option for Muslim believers but to except and obey it. If the Sunnah of the Prophet Muhammad says so, it means that there is blessing in it.

He further explained that the commands of the Qur'an and the Sunnah should be part of Muslims' lives. To this end, Muslims should imitate the Prophet Muhammad, the living Qur'an, and the perfect Muslim model. When asked about the Prophet's character, 'Aishah, the Prophet's wife, responded that his character was the Qur'an. His journey was not easy and it took time but Sugiono eventually felt that Salafism was the model of Islam he had been looking for. Being a Salafi means that he should put aside his nafsu (ego), which tends to lead to self-destruction, and submit himself to Allah's guidance. This means that he should behave in ways following the teachings of His Messenger. He always tried to practice Islam as much as possible. Starting from individual obligations like praying, fasting, and giving alms during Ramadhan, up to faḍa'il al-a'māl (recommended deeds) such as sporting a beard and pulling his pants above his ankles. To let the 
trousers touch the ground (isbāl) is considered excessive and is prohibited in Islam. All these things should be done in expectation of God's rewards.

Nafis's story is different. When he came to the Ma'had for the first time, he was surprised to find that most students sported long beards, which in Indonesian culture is unpopular. Only if a man has a thick beard he would not let it grow because a man who lets his thin beard grow might be called a "goat". In his family, no one had a beard, including his father. When he expressed his amazement at what he had seen to his father, his father explained that having a beard is closely related to Arabian culture. After some time he found that wearing a beard was recommended. "My God recommended me to wear a long beard and to clip my moustache." "Two things are fitrah: clipping the moustache and sporting a beard" (narrated by Muslim). He eventually decided to grow a long beard even if it was very thin. Another hadith says that wearing a long beard is a token to differentiate between Muslims and polytheists. He also removed the rims of his pants. Wearing long pants is tabdhìr (waste) and it is forbidden. When his family first saw the changes he made, his family was surprised but they eventually understood why he had made them. His father eventually decided to sport a long beard too just to show his respect for him.

Sugiono combined his training with his alertness against bid'ah. All the Salafi ulama agree on the prohibition of bid'ah including the so-called bid'ah hasanah (good bid'ah) traditionalist Muslim groups claim are allowed. Salafi students have been trained about the danger of bid'ah long before they attended the Ma'had. They reject any form of bid'ah traditionalist students allow. As a result, the Ma'had had become a battlefield between Salafi and traditionalist students. He said that this was a good example of why $d a^{\prime} w a h$ salafiyah should be promulgated. It should be done with wisdom and good advice, and, when necessary, with argumentative reasoning. He himself had seen that many of his friends indulged in bid'ah. He would just keep quiet and wait for the right time to act and talk. He had used this strategy during his training in his Ma'had. He approached the local population, listened to their arguments and eventually he would talk. As a 
result, he said, they gradually abandoned their bid'ah. He personally did not agree with Salafi students who promote Salafism without using this kind of strategy. The Prophet himself, he said, needed twenty-three years to promote his teachings among the Quraish population. In the Ma'had, religious training and alertness against the danger of bid'ah have been combined into the overall learning method. Moreover, through its teachers, the Ma'had provides spiritual guidance to the students and through this process the students gradually turn into Salafis.

\section{"Purification Clinic"}

Apart from spiritual training, the Ma'had has a "purification clinic". It refers to the programs the Ma'had offers where students are urged to watch videos on da'wah salafiyah. However, the $d a^{\prime} w a h$ salafiyah is limited to the $d a^{\prime} w a h$ as formulated by Saudi-Wahhabi scholars. It begins with the history of Muhammad ibn 'Abd alWahhāb who is credited with upholding the banner of tawhìd, which his successors have continued up to modern times with contemporaries including Bin Bāz and his students. Apart from that, the videos also showed the generosity of the Saudi royal families and their commitment to support Islamic $d a^{\prime} w a h$. Here Salafism is coupled with Saudi propaganda. Non-Salafi-Wahhabi religious scholars do not feature at all in the videos.

The clinic reportedly offers a positive contribution to the purification of the students, the degree to which may vary from one student to the other. Students who previously studied in Salafi madrasa are more confident in their Salafi way of life. Meanwhile traditionalist students have gradually moved toward puritanism. Nașhiruddīn, a traditionalist student who graduated in 2010, argued that many traditionalist students were likely to abandon excessive rituals around the dead, which require much energy and money. Although they still believe that these rituals are recommended, which is the original ruling, it is better to give up excessive rituals. Despite this purification tendency, traditionalist students claim not to be interested in Salafism. They just seek knowledge.

The Ma'had officially does not produce Salafis. Salafi-ness is resulted from complex relationships between the students and 
Saudi Sheikhs, many of whom are Wahhabi-Salafi scholars. Some scholars teaching at the Ma'had, including Indonesian scholars, are open-minded. Despite this complexity, he was able to differentiate between the official attitudes of the Ma'had and the Salafi tendency within the Ma'had. Many of his classmates want to become Salafis and they asked him to join. He replied that he had already become a Salafi before coming to the Ma'had. He argued that all Muslims were Salafi, only the degree to which differed from one person to another.

Most students believe that the Ma'had has in fact given a positive contribution to the development of their religious understanding - including their understanding of Salafism. Students with different backgrounds come to the Ma'had: Salafis, and members of the NU, Muhammadiyah, Persis, and the Jama'ah Tabligh. In this institution, they are forced to share their ideas. It is undeniable that some Salafi groups are extreme in their religious attitudes and they not only accuse other groups of being bid'ah practitioners, they even attack and prosecute them. The many incidents that took place in the country and that were allegedly committed by Salafis just give Salafism a bad name. The best way to resolve this problem is to integrate Salafi groups into the wider Muslim community rather than to isolate and reject them.

Integration and social relations between students create mutual understanding. This is exactly what happens in the Ma'had. Salafi students tend to become more open and respectful of other groups. Contrarily, NU students tend to become more orthodox. Nafis gave me as example that many NU friends now pray tarāwin (the additional prayers during the month of Ramadhan) with eleven raka'ah (cycles), which he believes is more accurate than twenty three raka'ah, and many NU friends do not read qunūt during the morning prayer. On the contrary, traditionalist students argue that the NU has for a long time perceived qunūt as sunnah (recommended) not wajīb (obligatory). They admit that sometimes they practice it, and sometimes they do not. Based on these stories, the students' understanding of Salafism widely varies. It depends upon their historical background e.g. modernist, traditionalist, as well as their social life 
inside and outside the Ma'had. Traditionalists, modernists, and Salafis share a great deal of Salafism as an authentic form of Islam.

The presence of Saudi Sheikhs, however, charged with upholding the right path of Islam and a huge collection of Wahhabi scholarship inevitably shapes the reproduction of the knowledge of the students. It tends to create uniformity among the Salafis. This tendency is resulted from the use of Salafi-Wahhabi scholarship that ignores the scholarship of the mainstream Sunni traditions. A number of primary courses such as aqidah and figh have become the specialty of the Saudi sheikhs. They also give lectures on Islam. Indonesian ustädh usually teach nahwwu (grammar) or particular Shafi'i books, secondary knowledge. They are also less paid compared to Saudis and non-Saudis. It is believed that Saudi Sheikhs serve as orthodoxy's guardians and they are considered more learned than Indonesian scholars. The Saudi Sheikhs regularly deliver sermons, lectures, seminars, and training for students. It is said that they were invited to enrich the students' understanding of Islam and to guard them from liberal fallacies. The term 'liberal' here refers to various study circles outside the Ma'had that blend contemporary Islamic ideas with Western post-modern philosophy. To the last point, many traditionalist students, many of whom claim to be a mbalelo (unruly) agree that they do not want to transgress the border.

\section{Same School, Different Paths}

The Ma'had offers networks to its students and these networks not only refer to careers and scholarships the students may get from Saudi Arabian institutions, but also patron-client relationships with Middle Eastern Salafi ulama. These factors considerably shape the transformation of Salafism in Indonesia. These differences can be seen, at least, in two different groups: the Wahdah and Laskar Jihad. While the Wahdah has been one of the most successful Salafi groups in creating its organizational networks with its Middle Eastern patrons, ${ }^{30}$ Laskar Jihad, after its

${ }^{30}$ Syarifuddin Jurdi, Sejarah Wahdah Islamiyah: Sebuah Geliat Ormas Islam di Era Transisi (Yogyakarta: Kreasi Wacana, 2007); Antony Bubalo and Greg Fealy, 
encounter with the Yemeni Salafi scholar, Muqbin bin Hadi alWadi'i, turned out to be a paramilitary organization. ${ }^{31}$

In the following section, I will describe two prototypes of students who influence the transformation of Salafism in Indonesia: Zaitun Rasmin from the Wahdah and Ja'far Umar Thalib from Laskar Jihad who died in August 2019. They have different social and historical backgrounds, social lives, and careers after they had discontinued their studies in the Ma'had which both did not finish. Their attachment to the Ma'had was just a stepping-stone through which they could connect with other Islamic institutions. Zaitun Rasmin, the founder of the Wahdah Islamiyah, has inherited the spirit of Islamic modernism as laid down by Indonesian modernist figures, who call upon Muslim to create modern institutions as well as to purify religious practices. Meanwhile, the escalation of the Muslim-Christian conflicts in post-Soeharto Indonesia gave rise to a Salafi paramilitary group called Laskar Jihad. Ja'far Umar Thalib, its former commander, is a Salafi teacher who was responsible for the deployment of this paramilitary group in Ambon and Poso, the two main conflict areas in the eastern part of Indonesia in the early 2000s. Claiming to be a purist, he renounced any political involvement and accused those involved in politics as hizbiyyah (factionalist). He had been involved in many conflicts with other Salafi figures, leading to the fragmentation of the Salafi groups in the country.

\section{A "Reformist" Salafi}

Long before attending the Ma'had, in the 1980s, Rasmin was a Muslim activist in Makassar, the capital of South Sulawesi Province. This region was previously popular for its traveling preachers who promoted Islam in other parts of the country. During the 1950s, the province became a hotbed of the Darul Islam

Joining the Caravan: The Middle East, Islamism and Indonesia (Sydney: Lowy Institute Paper, 2005).

${ }^{31}$ Noorhaidi Hasan, Laskar Jihad: Islam, Militancy and the Quest of Identity in Post New Order Indonesia (Ithaca: Cornell Southeast Asia Program Publications, 2006); Laurent Bonnefoy, "How Transnational Is Salafism in Yemen?," in Global Salafism, Islam's New Religious Movement, ed. Roel Meijer (London: C. Hurst \& Co. Publishing Ltd., 2009), 321-341. 
movement, a separatist organization that attempted to create an Islamic state. ${ }^{32}$ During the New Order, Makassar experienced one of the largest Islamic movements in the region. Together with his friend, Hasyim, Rasmin clandestinely organized a study club to discuss Islamic issues. At that time, the authoritarian New Order regime tightened its control over Muslim activists. The 1983 tragedy in Tanjung Priok, a district in the north of Jakarta, in which hundreds of Muslim activists had been killed or went missing, changed the direction of their movement. The tragedy was remarkable because a number of the victims were of Buginese or Makassarese ethnic backgrounds, the two main ethnic groups in South Sulawesi, who had close relations with the local activists. Amir Bikki, one of the Muslim public speakers killed in the incident, had been very popular among the activists and they circulated and reproduced his cassettes among themselves.

In the aftermath of this incident, Rasmin and Hasyim agreed to re-orient their movement and they urged all their cadres return to school or to a madrasa. One day, as every day, they held a religious gathering and suddenly they realized that none of them was able to read or understand Arabic. They looked at each other and did not know what to say. Like many other activists, Rasmin read about Islam from translated books especially those written by Ikhwans such as Sayyid Qutb (1906-1966), Hasan al-Banna (19061949), Said Hawwa (1935-1989), and Taqi al-Din al-Nabhani (19091977). Thanks to the modernist Muhammadiyah, he was exposed to more modernist ideas, which later on shaped his movement. Fathul Mu'in Daeng Magading, a local Muhammadiyah leader, reportedly had said that he would give his van to anyone who could convince him of the legitimacy of the twenty-three raka'ah (cycles) of the tarāwinh (supplementary prayer during the nights of Ramadhan). As known, the number of raka'at of the tarāwinh has always been controversial. Traditionalist NU perform twentythree cycles, while modernist Muhammadiyah only eleven. Although Rasmin was not really interested in khilafiyah (religious

${ }^{32}$ C. van Dijk, Rebellion under the Banner of Islam: Darul Islam in Indonesia (The Hague: Martinus Nijhoff, 1981); van Bruinessen, “Genealogies of Islamic Radicalism." 
disputes) issues, the modernist legacy nevertheless shaped his ideas. He is one of the modernist Muslim figures who brought back and even redefined Salafism within modernist circles.

In the mid-1980s, Rasmin headed to Jakarta but he only studied at the Ma'had for three semesters after which he left for the Islamic University of Medina. He enrolled at the Faculty of Sharia and studied with prominent Saudi scholars such as Sheikh Bin Bāz and Sheikh al-Uthaymīn. After finishing his study in the early 1990s, he worked in various Saudi international bodies including the International Islamic Relief Organization (IIRO) and the World Muslim League (WML). Having thus obtained these connections, he linked his nascent organization at home to these international Islamic bodies. He supported Wahdah cadres to pursue their advanced degrees at Saudi universities and many young Wahdah students were given this opportunity. At the same time, he managed to approach Saudi donors to establish a Ma'hadlike institute in Makassar called STIBA (Institute for Islamic Science and Arabic) which was subsequently used as a long distant-class for the Islamic University of Medina.

In 1998, Rasmin returned to his hometown. At the time, the political climate was very heated. Many rumors circulated among the public of the possibility of a return to the tightened policies of the New Order. Other rumors said that Soeharto was a sinking ship and that conservative Islamism should not save him from sinking. Believing that the political situation was improving, in 1998, Rasmin and his colleagues took advantage of this moment to transform the legal status of their organization from a yayasan (foundation), founded in 1988, to an organisasi massa (mass organization). With this new status, the Wahdah was able to expand its activities and it created branches in every province in the country. All the cadres and the Muslim people who expected the Wahdah to have an important role in building Muslim communities in the region applauded this decision.

\section{A "Revivalist" Salafi}

Ja'far Umar Thalib (born 1961) was once the most important Salafi figure and who had shaped the history of Salafi groups in 
Indonesia. ${ }^{33}$ Although many Salafi leaders despise him, his influence remains remarkable. In 2000, he founded a Muslim militia that was subsequently deployed in Ambon and Poso, two areas where Muslims and Christians were in conflict. He believed it was obligatory to defend fellow Muslims against Christian assaults. Many Salafi figures were disappointed with Ja'far's leadership and his violations on the Salafi manhaj. They requested the fatwa from the Salafi ulama in Saudi Arabia on this matter. In 2002, Sheikh Rabi'i bin Hadi al-Wadi'i, the Saudi grand mufti and successor of Sheikh Bin Baz, issued an edict which stated that Ja'far had gone astray from the true path of Salafism. He was barred from entering Saudi Arabia for seven years (2001-2008). At home his colleagues opposed him. Nevertheless, he challenged his opponents to take a mubahala, ${ }^{34}$ but no one was willing to do it.

In the aftermath of the Bali Bombing in 2005, Ja'far made the alarming statement that Abu Bakar Ba'asyir, the religious scholar who was previously involved in a clandestine movement against the authorities, was behind the attacks as he promoted Kharijite ideologies. The term Kharijite refers to an extremist group who denounced the leadership of Caliph Ali ibn Abi Thalib and of Mu'awiyah bin Abi Sufyan following the Battle of Siffin in $657 \mathrm{CE}$ and declared both as infidels due to their negligence of the laws of God. It is relevant to note that despite the fact that Ja'far once sent paramilitary troops to Ambon and Poso, he argued that all he did was to defend the integrity of the Republic of Indonesia against separatist groups in Maluku. When the separatists would have been eradicated, he further asserted, he would disband the militia and he had no intention whatsoever of establishing an Islamic State. Due to his anti-separatist attitude, he was and remains close to the Indonesian military. Nowadays, he is frequently invited by the Indonesian National Contra-Terrorism Agency (BNPT) to offer his ideas on combating terror attacks in the country. ${ }^{35}$

${ }^{33}$ Hasan, Laskar Jihad; Jamhari and Jajang Jahroni, eds., Gerakan Salafi Radikal di Indonesia (Jakarta: Rajawali Press, 2004).

${ }^{34}$ Mubahalah is a mechanism where two challenging people take an oath in the name of God in front of the public to demonstrate their self-truth and the fallacies of their challengers.

${ }^{35}$ Interview with Ja'far Umar Thalib, Yogyakarta, February 15, 2011. 
Ja'far was born to a Hadhrami family in Malang, East Java. He received his early education in a madrasa of al-Irshad, a modernist group founded by Sheikh Ahmad Soorkati. His ancestors were peripatetic scholars and preachers who had migrated from Yemen to the archipelago in the mid-nineteenth century and who had strong puritanical inclinations. It is hardly surprising that he grew up as a non-compromising figure. In the early 1980s, he studied at the Ma'had in Jakarta but did not graduate. He disputed with Sheikh Yasin, one of the teachers in the Ma'had and he did not agree with the subject Sheikh Yasin taught namely the Matan alGhayah wal al-Taqrib - popularly called Matan Abu Shuja -a text composed by the medieval Shafi'i scholar Abu Shuja Ahmad ibn Hasan al-Isfahani (1138-1197). This book is very popular among traditionalist NU Islamic boarding schools across the country. He considered that the subject was useless since it was devoid of references to the Qur'an and the Sunnah. Each time Yasin came into the class, he stood up and left. Knowing that he was a brilliant student, the Director of the Ma'had, 'Abd al-'Azīz ibn 'Ammar offered him a scholarship to study in Pakistan. He then studied at the Mawdudi Institute in Lahore but only stayed for less than a year. He was obsessed with crossing the border to join the Afghan mujīhid (fighters) against the communist Soviets. He claimed to have joined Gulbuddin Hekmatyar's faction but he eventually joined the Salafi faction called Jama'ah Da'wah ila al-Qur'ān wa alSunnah. In Afghanistan, his Salafi commanders, many of whom were contingents from the Middle East, taught him many military skills such as guerilla tactics and strategies.

Returning from Pakistan in 1989, he taught at Pesantren Tengaran in Central Java, but only lasted for three months. He was ousted by the pesantren board due to his severe methods. In 1990, he flew to Dammaj in Yemen, where he met Sheikh Muqbil bin Hadi al-Wadi'i, who eventually shaped his knowledge further. In al-Wadi'i, he found the ideal type of Salafi scholar who combined fortitude, humility, and knowledge. In his Tuhfah al-Muhīb 'alā As'ilati al-hạdir wal Gharīb (The Loved Gift for the Questions by the Present and Distant Friends), al-Wadi'i described Ja'far as a learned Indonesian student who, despite having lived for only a short period in Dammaj, could benefit much from his study. 
Meanwhile, Ja'far described his teacher as a learned and Godfearing person who dedicated his life for the avocation of the Qur'an and the Sunnah. His encounter with al-Wadi'i is interesting for a number of reasons. First, Al-Wadi'i was expelled from Saudi Arabia following Juhaymān al-'Utaybī's short seizure of the Grand Mosque of Mecca in 1979. He was accused of being involved in the coup. Returning to his hometown Dammaj, he founded Dār al-Sunnah, specializing on hadith. In this tiny town, he taught hadith and his popularity attracted students from all over the Muslim world. Second, al-Wadi'i had faced extremely difficult times during all of his life until his death in 1999. In the barren dessert, he had to face San'a's secular regime, Shiite opposition to which a significant number of the Yemeni ethnic group al-Houthi subscribe, warlords, and extremist groups. Third, through alWadi'i's leadership, Ja'far not only saw him as the prototype of a Salafi scholar who fought with his pen, but also as a fighter who commanded his troops to combat the enemies of Islam.

\section{From Assertive Politics to Quietism}

According to Ja'far, formal politics is haram (unlawful) thus he can be categorized as belonging to the first group. Many Salafi classical thinkers such as Ibn Taymiyya up to modern scholars such as Nașiruddīn al-Albani reiterated quietism in relation to politics. In practice, Salafi communities often violate this principle. Quietists secretly offer advice to the rulers while distancing themselves from them. A deep immersion in politics, according to this group, would certainly distract the people's attention and energy away from da'wah and tarbiyah's main obligation.

In Ja'far's experience, the political pendulum of the Salafis moves between quietism and assertive politics. Unlike Rasmin, who was more concerned with $d a^{\prime} w a h$ and education as well as constantly offering advice to the authorities, Ja'far displayed a belligerent attitude. According to him, jihad for defensive reasons was permissible and should be undertaken under ulama guidance. For this reason, he had created his paramilitary group under alWadi'i's guidance, and it was disbanded on the very same day alWadi'i issued a fatwa to do so. He argued that he never had any intention to oppose the rulers, nor had he ever provoked his 
followers to create a separate state as it is against Salafi teachings. In the course of history, Salafis always supported their rulers regardless whether they were just or not. During the interview with him on February 2012, to support his argument, he related the story of Ahmad bin Hanbal, one of the most respected Salafi ulama, who continued to pray for the caliph. When his son asked him why he kept praying for the caliph despite his cruelty against him, he answered that if he knew one request to be granted by God, he would have prayed for the ruler's enlightenment and forgiveness.

In the post-Laskar Jihad period, Ja'far lost many of his followers at home and his patrons abroad. Although he was able to maintain his connections with the Saudi religious establishment, some senior members still dismissed him. This had consequences for the Salafi groups in Indonesia. His colleagues even refused to see him. He returned to his madrasa in Kaliurang, Yogyakarta. Realizing that many Salafi figures despised him, he admitted not to have made any provocative statement that might worsen the situation as he was just a guru ngaji (religious teacher).

\section{Conclusion}

Claiming to be an Islamic state, Saudi applies an Islamic law which is rooted in the ideas of Muhammad ibn 'Abd al-Wahhāb, the founder of Wahhabism, who initiated the establishment of Saudi Arabia. In the modern time, Saudi Arabia seeks to promote its education system beyond its border. This approach is to make Muslim countries to be in its orbit as its global strategy to maintain its hegemony. In the modern time, Wahhabism is interchangeable with Salafism as a result of Saudi campaign.

The Ma'had is a Saudi Arabia project. It has significantly played an important role in promoting and distributing Salafism to Indonesian students. It is a state institution to promote state ideology and Saudi interests to Indonesia as the largest Muslim country in the world. Through various scholarship this institute attracts Muslim students to come to study. The modernists, the traditionalists, the Salafi, and the Tablighis come to the Ma'had with the reason of acquiring religious knowledge. 
Despite the Saudi state seeks to control the reproduction of knowledge within the Ma'had, the students are able to shape their knowlede on their own. It is not an exaggeration to say that the Ma'had has become the melting pot where students are shaping and being shaped by the Ma'had. Unlike the general assumption about the Ma'had which tends to see it as a monolithic entity, the reproduction of knowledge of students have been so diverse. This is due to the fact that students are coming from different backgrounds. They are also exposed to different social life outside the Ma'had.

After finishing their studies, students are exposed to different network provided by Saudi Arabia. While enjoying Saudi patron, students develop their own strategies in order to be compatible with the Indonesian context. They reinterpret the meaning of Salafism as can be seen in the life of two students, Zaitun Rasmin and Ja'far Umat Thalib, who become the role models for other students.

\section{References}

Abouhaseira, Maher. "Education, Political Development and Stability in Saudi Arabia." Ph.D. Dissertation, University of Southern California, 1998.

Al-Hefdhy, Yahya S. "The Role of the Ulama (Islamic Scholars) in

Establishing an Islamic Identity for Women in Saudi Arabia."

Ph.D. Dissertation, The Florida State University, 1994.

Al-Rasheed, Madawi. A History of Saudi Arabia. Cambridge:

Cambridge University Press, 2002.

- - - Kingdom without Borders, Saudi Arabia's Political, Religious and Media Frontier. London: Hurst \& Company, 2008.

Barth, Fredrik. Balinese World. Chicago: The University Press of Chicago, 1993.

Bonnefoy, Laurent. "How Transnational Is Salafism in Yemen?" In Global Salafism, Islam's New Religious Movement, edited by Roel Meijer, 321-341. London: C. Hurst \& Co. Publishing Ltd., 2009. Bourdieu, Pierre. Outline of a Theory of Practice. New York: Cambridge University Press, 2007. 
van Bruinessen, Martin. "Genealogies of Islamic Radicalism in Post-Suharto Indonesia." South East Asia Research 10, no. 2 (2002): 117-154.

Bubalo, Antony, and Greg Fealy. Joining the Caravan: The Middle East, Islamism and Indonesia. Sydney: Lowy Institute Paper, 2005.

Damanik, Ali Said. Fenomena Partai Keadilan, Transformasi 20 Tahun Gerakan Tarbiyah di Indonesia. Jakarta: Teraju, 2002.

Delong-Bas, Natana J. Wahhabi Islam: From Revival and Reform to Global Jihad. New York: Oxford University Press, 2004.

van Dijk, C. Rebellion under the Banner of Islam: Darul Islam in Indonesia. The Hague: Martinus Nijhoff, 1981.

Fortna, Benjamin C. Imperial Classroom: Islam, the State and Education in the Late Ottoman Empire. Oxford: Oxford University Press, 2000.

Foucault, Michel. Power/Knowledge: Selected Interviews and Other Writings, 1972-1977. Edited by Colin Gordon. 1st American Ed edition. New York: Vintage, 1980.

Geertz, Clifford. The Religion of Java. Chicago: University of Chicago Press, 1976.

Gilsenan, Michael. Recognizing Islam, Religion and Society in the Modern Middle East. London and Canberra: Croom Helm, 2000.

Hasan, Noorhaidi. Laskar Jihad: Islam, Militancy and the Quest of Identity in Post New Order Indonesia. Ithaca: Cornell Southeast Asia Program Publications, 2006.

- - - "Saudi Expansion, The Salafi Campaign and Arabized Islam in Indonesia." In Kingdom without Borders, Saudi Arabia's Political, Religious and Media Frontier, by Madawi Al-Rasheed, 263-282. London: Hurst \& Company, 2005.

Hefner, Robert W. Hindu Javanese: Tengger Tradition and Islam. Princeton, NJ: Princeton University Press, 1989.

Hefner, Robert W., and Muhammad Qasim Zaman, eds. Schooling Islam: The Culture and Politics of Modern Education. Princeton, NJ: Princeton University Press, 2007.

Hegghammer, Thomas, and Stephane Lacroix. "Rejectionist Islamism in Saudi Arabia: The History of Juhayman al-Utaybi Revisited." International Journal for Middle East Studies 39 (2007): 103-122. 
Husin, Asna. "Philosophical and Sociological Aspects of Da'wah: A Study of Dewan Dakwah Islamiyah Indonesia." Ph.D. Dissertation, Columbia University, 1998.

Jahroni, Jajang. "The Political Economy of Knowledge: Sharia and Saudi Scholarship in Indonesia." Journal of Indonesian Islam 7, no. 1 (June 2013): 165-186.

Jamhari, and Jajang Jahroni, eds. Gerakan Salafi Radikal di Indonesia. Jakarta: Rajawali Press, 2004.

Jurdi, Syarifuddin. Sejarah Wahdah Islamiyah: Sebuah Geliat Ormas Islam di Era Transisi. Yogyakarta: Kreasi Wacana, 2007.

Makdisi, George. The Rise of College, Institutions of Learning in Islam and the West. Edinburgh: Edinburgh University Press, 1981.

Meijer, Roel, ed. Global Salafism: Islam's New Religious Movement. London: C. Hurst \& Co. Publishing Ltd., 2009.

Noor, Farish A, Yogindar Sikand, and Martin van Bruinessen, eds. Madrasa in Asia: Political Activism and Transnational Linkages. Amsterdam: Amsterdam University Press, 2008.

Peacock, James L. Muslim Puritans: Reformist Psychology in Southeast Asian Islam. Berkeley: University of California Press, 1978.

Prokop, Michaela. "Saudi Arabia: The Politics of Education." International Affairs 79, no. 1 (1994): 77-89.

Rahmat, Imdadun. Arus Balik Islam Radikal. Jakarta: Erlangga, 2005. Saleh, Fauzan. Modern Trends in Islamic Theological Discourse in Twentieth Century Indonesia, a Critical Survey. Leiden: E. J. Brill, 2001.

Smith-Hefner, Nancy J. “The New Muslim Romance: Changing Patterns of Courtship and Marriage among Educated Javanese Youth." Journal of Southeast Asian Studies 36, no. 3 (2005): 441459.

Starret, Gregory. Putting Islam to Work: Education, Politics and Religious Transformation in Egypt. Berkeley: University of California Press, 1998.

Wahid, Din. "Nurturing The Salafi Manhaj: A Study of Salafi Pesantrens in Contemporary Indonesia." Ph.D. Dissertation, Utrech University, 2014. 